Original Research Paper

\title{
Toxicity of Endosulfan to the Red Hybrid Tilapia
}

\author{
Dwight E. Robinson and Winroy Williams \\ Department of Life Sciences, University of the West Indies, Mona, Kingston 7, Jamaica
}

Article history

Received: 24-02-2015

Revised: 04-03-2015

Accepted: 04-03-2015

Corresponding Author: Dwight E. Robinson

Department of Life Sciences, 4 Anguilla Close,

University of the West Indies, Mona Campus,

Kingston 7, Jamaica

Tel.: (876) 927-1202

Email: dwight.robinson@uwimona.edu.jm

\begin{abstract}
Exposure of mature red hybrid Tilapia sp. to a range of sublethal concentrations of endosulfan for 21 days induced a spectrum of often not clearly distinguishable Behavioural Toxic Symptoms (BTS), ranging from reversible to eventually fatal responses. The No Observed Effect Concentration (NOEC: Below the threshold of BTS) and the Lowest Observed Effect Concentration (LOEC: Above the threshold of low intensity and reversible BTS and below the threshold of any mortality) were $<0.005$ and $<0.0075 \mathrm{mg} \mathrm{L}^{-1}$, respectively. Two other categories of BTS were also distinguishable. Medium Observed Effect Concentration (MOEC: Reversible, medium-intensity BTS in $75 \%$ and pronounced, lethal BTS in 25\% individuals) and Pronounced Observed Effect Concentration (POEC: Leading to mortality of $>25 \%$ to $50 \%$ of the fish) were 0.01 and $0.02 \mathrm{mg} \mathrm{L}^{-1}$, respectively. The 3-day and 21-day $\mathrm{LC}_{50}$ values were 0.031 and $0.016 \mathrm{mg} \mathrm{L}^{-1}$, respectively.
\end{abstract}

Keywords: Endosulfan, Toxicity, Tilapia

\section{Introduction}

Hillside farming, rainfall pattern, poor agronomic practices, which can all contribute to soil erosion, have rendered small Caribbean islands agro-ecosystems vulnerable to run-off of pesticide residues (Mansingh, 1993; Robinson et al., 1997; Mansingh et al., 2003). Pesticide residues have contaminated several Jamaican rivers, which drain the agricultural valleys and coastal waters (Mansingh, 1993; Mansingh et al., 1997; 2003). Residues of endosulfan (which was used extensively against the Coffee Berry Borer, Hypothenemus hampei Ferrari, in the Blue Mountains and highlands up until 2011) were detected in many wells and springs and in almost all the rivers, coastal waters and aquatic fauna in Jamaica during the 1990s (Robinson and Mansingh, 1999; Witter et al., 1999).

Toxic chemicals can affect non-target organisms by causing hormone imbalances and disruption and can lead to a variety of physiological effects such as abnormal growth and reproduction (Oberdörster and Cheek, 2001). In order to monitor possible impacts of pesticides on the aquatic ecosystem it is necessary to determine the ecotoxicity potential of pesticide residues to the fauna inhabiting these ecosystems. With a history of varying levels of endosulfan residues being detected in Jamaican water, the present study was designed to investigate the reversible and non-reversible toxic effects of sub-lethal concentrations and acute toxicity levels of endosulfan on an indicator species, the hybrid Red Tilapia fish. The objective was to attain an insight into the ecotoxicity potential of the insecticide in Jamaican river and coastal waters.

\section{Materials and Methods}

Sexually mature individuals of the Red Hybrid tilapia (8-9 cm long) were obtained from a commercial farm and held in aerated glass aquaria for at least two weeks for acclimatization. Fish meal was provided daily and water was changed every three days.

Six $20 \mathrm{~L}$ glass aquaria with $18 \mathrm{~L}$ water were aerated for $24 \mathrm{~h}$ before the required amount of Thiodan 35EC (supplied by Hoescht, Germany; purity, checked by Gas Chromatograph (GC); $33.75 \%$ active ingredient) was added to the experimental aquaria and the water agitated manually for $5 \mathrm{~min}$. About $30 \mathrm{~min}$ later, 18 fishes were introduced into each of the experimental and control aquaria. The fish were not fed for the first three days, but food pellets were provided everyday thereafter, in small amounts, to ensure as little left-over as possible. Each experiment was conducted in triplicate.

The fishes were exposed to different concentrations of endosulfan, ranging from 0.0025 to $0.025 \mu \mathrm{g} \mathrm{L^{-1 }}$. Toxic symptoms (darting, shuddering, side swimming and mortality) were recorded every $8 \mathrm{~h}$ for the first 3 days, every $12 \mathrm{~h}$ for the next 4 days and every $24 \mathrm{~h}$ for 
the next 2 weeks. The concentration of endosulfan in the water was checked by GC. For determining the 3-day $\mathrm{LC}_{10-95}$ of endosulfan, the fishes were exposed to six concentrations of endosulfan, ranging from 0.02 to 0.04 $\mathrm{mg} \mathrm{L}^{-1}$ of its active ingredient for $24 \mathrm{~h}$. Fish mortality was recorded and the data subjected to Probit analysis.

Concentration of endosulfan in the aquarium water was checked at 0 and 3 days after introduction of the insecticide, by extracting the residues from $100 \mathrm{~mL}$ aliquots of water, according to the UNEP methodology described by Robinson and Mansingh (1999).

\section{Results}

No toxic symptoms were observed in the control fish or those exposed to $0.0025 \mathrm{mg} \mathrm{L}^{-1}$ of endosulfan for 21 days (Table 1). However, exposure to $0.005 \mathrm{mg} \mathrm{L}^{-1}$ induced slight toxic symptoms, such as darting and shuddering, in $14 \%$ of the fish, from which they recovered 12-24 h later. At $0.0075 \mathrm{mg} \mathrm{L}^{-1}$, most of the $29 \%$ fish affected displayed pronounced toxic symptoms of side-swimming, from which $14 \%$ could not recover. Almost all the fish exposed to residues ranging from 0.01 to $0.025 \mathrm{mg} \mathrm{L}^{-1}$ were visibly affected and 30 to $90 \%$ of them succumbed. Pronounced toxic symptoms were visible in most fish within 30-60 min of exposure to 0.02 and $0.025 \mathrm{mg} \mathrm{L}^{-1}$, which caused 12 to $45 \%$ mortality within 2 days. At the end of the 21-day exposure to these concentrations, 73 to $90 \%$ of the fish had died, 5 to $10 \%$ were still alive but appeared sick, while 5 to $17 \%$ had recovered.

The 21-day and 3-day $\mathrm{LC}_{10-95}$ data are presented in Table 2; lethal concentrations ranged from 0.008-0.049 $\mathrm{mg} \mathrm{L}^{-1}$. In the 3-day acute toxicity experiments, mortality at higher concentrations occurred within $24 \mathrm{~h}$. Some of the individuals which did not die displayed pronounced toxicity symptoms even after 3 days of exposure.

\section{Discussion}

Ecotoxicity of insecticides depends upon the concentration and physico-chemical properties of the chemical, the physiological and developmental state of the species and the extent of exposure to the toxicant (Lyman, 1995). It induces invisible, reversible or irreversible physiological lesions, which are manifested through a spectrum of behavioural responses, some of which may not be qualitatively identifiable, others more pronounced and deadly. Though it is almost impossible to categorize a fluid and often reversible physiological phenomenon of toxicity, quantification of visible toxic symptoms is essential for rapid assessment of ecotoxicity of a pesticide.
Based upon the acute lethal toxicity of a compound to a test organism over a period of time, Strik (1990) suggested the terms Non-Observed Effect Concentration (NOEC) and Lowest Observed Effect Concentration (LOEC) for the visible acute toxicity to the least number of individuals. Ellersiek at al. (1994) and Lee et al. (1995) recommended extrapolation of acute toxicity data for the calculation of NOEC and LOEC. A two step linear extrapolation of data to a dose at which toxic effects are arbitrarily small and acceptable and the other at which no more than $25 \%$ are affected was suggested by Hoekstra and van Ewijk (1993)

Such criteria are valid for small test organisms such as Daphnia spp. However, the present results suggest that data on the reversibility or irreversibility of visible toxic effects may be more applicable in the assessment of toxicity of a compound than the acute toxicity data. Robinson et al. (2002) provided data on the reversibility of visible toxic symptoms in the shrimp Macrobrachium faustinum De Sassure, which were exposed to sub-lethal concentrations of dieldrin. They suggested that NOEC be defined as the concentration just below the threshold of any observable behavioural toxic symptom and LOEC, just above the threshold of mild- and low-intensity, reversible toxic symptoms and below the threshold of mortality. Two new terms were proposed for medium and pronounced toxic symptoms, which may or may not be reversible. Medium Observed Effect Concentration (MOEC) was defined for visible toxic symptoms in most individuals, leading to $50 \%$ mortality and Pronounced Observed Effect Concentration (POEC) for pronounced toxic symptoms in most individuals, leading to over $50 \%$ mortality.

The present data support the suggestion of Hoekstra and van Ewijk (1993) of extrapolating acute toxicity data for the calculation of LOEC. The data on the reversible toxicity to the fish (Table 1) and the 21-day $\mathrm{LC}_{10-95}$ data (Table 2) are comparable. Both sets of data indicate that NOEC, when no toxic symptoms were visible, may be established at $<0.005 \mathrm{mg} \mathrm{L}^{-1}$; LOEC, which is just below or at the threshold of toxicity, may be $\mathrm{LC}_{5}$, which is $<0.0075 \mathrm{mg} \mathrm{L}^{-1}$; MOEC at $\mathrm{LC}_{30}$, which is $<0.015 \mathrm{mg} \mathrm{L}^{-1}$ and POEC at $\mathrm{LC}_{75}$.

Most of the test organisms which recover from manifested toxic symptoms, depending on the concentration of the chemical and extent and exposure, may suffer adverse physiological effect, which could influence their reproduction and survival (Robinson et al., 2002; van Leeuwen and Hermens, 1995). Indeed, NOEC and LOEC levels of dieldrin caused the resting Oxygen Consumption Rate $\left(\mathrm{VrO}_{2}\right)$ of Macrobrachium faustinum to increase by $48 \%$, while the active Oxygen Consumption Rate $\left(\mathrm{VaO}_{2}\right)$ decreased by $13 \%$. The $\mathrm{VrO}_{2}$ and $\mathrm{VaO}_{2}$ in $M$. amazonicum also decreased by 43 and 70\%, respectively (Lawrence et al., 1986a; 1986b). 
Table 1. Toxic symptoms of endosulfan to the Red Hybrid Tilapia, after 21-day exposure to different concentrations, under static conditions $\%$ fish with specific symptoms ${ }^{1}$ at different days

\begin{tabular}{|c|c|c|c|c|c|c|}
\hline Conc. $\left(\mathrm{mg} \mathrm{L}^{-1}\right)$ & 3 & 7 & 10 & 14 & 21 & $\begin{array}{l}\text { Total \% displaying toxic } \\
\text { symptoms in } 21 \text { days }\end{array}$ \\
\hline Control & 0 & 0 & 0 & 0 & 0 & $0 ;$ all normal \\
\hline $0.0025 \pm 0.0003$ & 0 & 0 & 0 & 0 & 0 & $0 ;$ all normal \\
\hline $0.005 \pm 0.0003$ & 0 & 0 & 0 & 0 & $7 \mathrm{~d} ; 7 \mathrm{~s}$ & 14 ; but all recovered \\
\hline $0.0075 \pm 0.0005$ & 0 & $5 d$ & $7 \mathrm{ss}$ & $17 \mathrm{ss} ; 5 \mathrm{~m}$ & $7 \mathrm{~m}$ & $29 ; 14$ died, 15 recovered \\
\hline $0.01 \pm 0.0008$ & $10 \mathrm{~d} ; 20 \mathrm{~s}$ & $10 \mathrm{~s}, 15 \mathrm{ss} ; 10 \mathrm{~m}$ & $10 \mathrm{ss} ; 10 \mathrm{~m}$ & $5 \mathrm{ss} ; 10 \mathrm{~m}$ & 0 & $85 ; 30$ died, 55 recovered \\
\hline $0.015 \pm 0.0008$ & $50 \mathrm{~s} ; 10 \mathrm{ss} ; 15 \mathrm{~m}$ & $40 \mathrm{ss}, 10 \mathrm{~m}$ & $20 \mathrm{ss} ; 5 \mathrm{~m}$ & $25 \mathrm{ss} ; 15 \mathrm{~m}$ & $10 \mathrm{ss}$ & $100 ; 45$ died, 55 recovered \\
\hline $0.02 \pm 0.001$ & $25 \mathrm{~d} ; 55 \mathrm{ss} ; 12 \mathrm{~m}$ & $25 \mathrm{ss} ; 15 \mathrm{~m}$ & $10 \mathrm{~d} ; 15 \mathrm{~m}$ & $10 \mathrm{ss} ; 20 \mathrm{~m}$ & $10 \mathrm{ss}$ & $100 ; 73$ died, 17 recovered \\
\hline $0.025 \pm 0.001$ & $25 \mathrm{~d} ; 10 \mathrm{~s}, 20 \mathrm{ss} ; 45 \mathrm{~m}$ & $25 \mathrm{ss} ; 30 \mathrm{~m}$ & $5 \mathrm{~s} ; 10 \mathrm{ss} ; 10 \mathrm{~m}$ & $5 \mathrm{ss} ; 5 \mathrm{~m}$ & $5 \mathrm{ss}$ & $100 ; 90$ died, 5 recovered \\
\hline
\end{tabular}

1. d- darting; m- mortality; s- shuddering; ss- side swimming

Table 2. Twenty-one day and three-day $\mathrm{LC}_{10}, \mathrm{LC}_{50}, \mathrm{LC}_{95}\left(\mathrm{mg} \mathrm{L}^{-1}\right)$ values of endosulfan for 8-9 $\mathrm{cm}$ long Tilapia, determined under static conditions

\begin{tabular}{lllll}
\hline Toxicity level & Duration & Concentration $\left(\mathrm{mg} \mathrm{L}^{-1}\right)$ & Fiducial limit & Slope \\
\hline $\mathrm{LC}_{10}$ & 21-day & 0.008 & $0.006-0.009$ & $4.137 \pm 0.308$ \\
$\mathrm{LC}_{50}$ & 21-day & 0.016 & $0.014-0.018$ & \\
$\mathrm{LC}_{95}$ & 21-day & 0.039 & $0.031-0.056$ & $8.185 \pm 1.598$ \\
$\mathrm{LC}_{10}$ & 3-day & 0.021 & $0.012-0.025$ & \\
$\mathrm{LC}_{50}$ & 3-day & 0.031 & $0.027-0.035$ & \\
$\mathrm{LC}_{95}$ & 3-day & 0.049 & $0.040-0.100$ & \\
\hline
\end{tabular}

Fenvalerate and chlorpyrifos also increased $\mathrm{O}_{2}$ consumption in the shrimp, Palaemnetes clara and $P$. pucio, respectively (McKenney and Hamaker, 1984). When exposed to 0.006 and $0.01 \mu \mathrm{g} / \mathrm{L}$ endosulfan for 96 $\mathrm{h}$, the fresh water shrimp Channa punctatus had reduced AchE activity and displayed behavioural toxic symptoms (Gopal et al., 1985). Sub-lethal dose of endosulfan also affected reproduction, fecundity and survival of fish hatchlings (Chakravorty et al., 1992). Larvae of the American lobster, Homarus americanus, had significantly higher levels of CYP45 (detoxification enzyme) and HSP70 (stress protein) for several days following exposure to the cyclodiene pesticide heptachlor (Snyder and Mulder, 2001). Delays in moultings were correlated with changes in ecdysteroid levels, which implied that the pesticide may have caused endocrine disruption in these crustaceans. Prolonged elevation in HSP70, due to pesticide exposure, was directly related to increased mortality. Additionally, Stueckle (2008) found that male fiddler crabs, Uca pugnax, had a higher incidence of abnormal limbs than female crabs at high permethrin concentrations and stressful salinity levels. Females also exhibited heightened respiration rates, which suggested increased metabolic rates. Hence, while recovery from toxic symptoms was observed in fish exposed to the lower concentrations (LOEC and MOEC), long term physiological impact may exist but not be evident.

\section{Conclusion}

Exposure of Tilapia fish to different sub-lethal doses of endosulfan induced a variety of toxic symptoms such as darting, shuddering and side-swimming. The data suggests a very high toxicity dose response gradient with the NOEC being below $0.005 \mathrm{mg} \mathrm{L}^{-1}$ and the LOEC being between 0.005 and $0.0075 \mathrm{mgL}^{-1}$ of endosulfan. At LOEC concentrations, the fish were able to recover; however, prolonged exposure resulted in POEC symptoms and increased levels of mortality.

\section{Author's Contributions}

All authors contributed equally to this work.

\section{Ethics}

This article is original and contains unpublished material. The corresponding author confirms that the other author has read and approved the manuscript and no ethical issues are involved.

\section{References}

Chakravorty, S., B. Lal and T.P. Singh, 1992. Effect of endosulfan (Thiodan) on vitellogenesis and its modulation by different hormones in the vitellogenic catfish, Clarias batrachus. Toxicology, 75: 191-198. DOI: $10.1016 / 0300-483 X(92) 90001-U$

Ellersiek, M.R., G.F. Karuse, K. Sun, G. Lee and F.L. Mayer, 1994. Prediction of chronic no-observed effect concentrations from acute toxicity data. Proceedings of the 15th Annual Meeting of the Society of Environmental Toxicology and Chemistry, Oct. 30-Nov. 3, Society of Environmental Toxicology and Chemistry, Pensacola, USA. 
Gopal, K., M. Anand, S. Mehrotra and P.K. Ray, 1985. Neurobehavioural changes in freshwater fish Channa punctatus exposed to endosulfan. J. Adv. Zool., 6: 74-80.

Hoekstra, J.A. and P.H. van Ewijk, 1993. Hazard assessment alternatives for the no-observed-effect level. Environ. Toxicol. Chem., 12: 187-194. DOI: $10.1002 /$ etc.5620120119

Lawrence, V., R.E. Young and A. Mansingh, 1986a. The effect of sub-lethal doses of dieldrin on the ventilatory and cardiac activity in two species of shrimps. Comp. Biochem. Physiol. C., 85: 177-181. DOI: 10.1016/0742-8413(86)90070-8

Lawrence, V., R.E. Young and A. Mansingh, 1986b. The effect of sub-lethal doses of dieldrin on resting and active metabolism in two species of shrimps. Comp. Biochem. Physiol. C., 85: 183-186. DOI: $10.1016 / 0742-8413(86) 90071-X$

Lee, G., M.R. Ellersieck, F.L. Mayer and G.F. Krause, 1995. Predicting chronic lethality of chemicals to fishes from acute toxicity test data: Multifactor Probit Analysis. Environ. Toxicol. Chem., 14: 345-349. DOI: $10.1002 /$ etc. 5620140221

Lyman, W.J., 1995. Transport and Transformation Processes. In: Fundamentals of Aquatic Toxicology: Effects, Environmental Fate and Risk Assessment, G.M. Rand (Ed.), CRC Press, ISBN-10: 1560320907, pp: 449-492.

Mansingh, A, D.E. Robinson and K.M. Dalip, 2003. Use, Fate and Ecotoxicity of Pesticides in Jamaica and the Commonwealth Caribbean. In: Pesticide Residues in Coastal Tropical Ecosystems: Distribution, Fate and Effects, Taylor, M.D., S.J. Klaine, F.P. Carvalho, D. Barcelo and J. Everaarts (Eds.). Taylor and Francis, London, ISBN-10: 0203165586, pp: 426-463.

Mansingh, A., 1993. Pesticide management-a global dilemma. Proceedings of the U.W.I.-OUSECUSAID-DT Workshop, May 26-29, St. Vincent and the Grenadines.

Mansingh, A., D.E. Robinson and K.M. Dalip, 1997. Insecticide contamination of the Jamaican environment. Trends Anal. Chem., 16: 115-123. DOI: 10.1016/S0165-9936(97)00006-X

McKenney Jr., C.L. and D.B. Hamaker, 1984. Effects of fenvalerate on larval development of Palaemonetes pugio (Holthuis) and on larval metabolism during osmotic stress. Aquat. Toxicol., 5: 343-355.

DOI: $10.1016 / 0166-445 X(84) 90015-8$
Oberdörster, E. and A.O. Cheek, 2001. Gender benders at the beach: Endocrine disruption in marine and estuarine organisms. Environ. Toxicol. Chem., 20: 23-36. DOI: $10.1002 /$ etc. 5620200103

Robinson, D.E. and A. Mansingh, 1999. Insecticide contamination of Jamaican Environment. IV. Transport of the residues coffee plantations in the blue mountains to coastal waters in eastern Jamaica. Environ. Monit. Assess., 54: 125-141. DOI: $10.1023 / \mathrm{A}: 1005806815959$

Robinson, D.E., A. Mansingh and T.P. Dasgupta, 1997. Fate of endosulfan in soil and in river and coastal waters of Jamaica. Proceedings of the International Symposium on the Use of Nuclear and Related Techniques for Studying Environmental Behaviour of Crop Protection Chemicals, Jul. 1-5, International Atomic Energy Agency, Vienna, pp: 301-311.

Robinson, D.E., C. Henry and A. Mansingh, 2002. Toxicity, bioaccumulation and tissue partitioning of dieldrin by the shrimp Macrobrachium faustinum De Sassure, in fresh and brackish waters of Jamaica. Environ. Technol., 23: 1275-1284. DOI: $10.1080 / 09593332308618319$

Snyder, M.J. and E.P. Mulder, 2001. Environmental endocrine disruption in decapod crustacean larvae: Hormone titers, cytochrome $\mathrm{P} 450$ and stress protein responses to heptachlor exposure. Aq. Toxicol., 55: 177-190. DOI: 10.1016/S0166-445X(01)00173-4

Strik, J., 1990. General ecotoxicology. Head, Quality Assurance Unit. National Institute of Public Health and Environmental Protection.

Stueckle, T.A., 2008. An evaluation of the non-target effects of mosquito control pesticides on Uca pugnax physiology, limb regeneration and molting processes. Ph.D. Thesis, West Virginia University.

van Leeuwen, C.J. and J.L.M. Hermens, 1995. Risk Assessment of Chemicals: An Introduction. 1st Edn., Kluwer Academic Publishers, pp: 430.

Witter, J.V., D.E. Robinson, A. Mansingh and K.M. Dalip, 1999. Insecticide contamination of Jamaican Environment. V. Island-wide rapid survey of residues in surface and ground water. Environ. Monitor. Assessment, 56: 257-267. DOI: 10.1023/A:1005959704697 